\title{
Bibliometric Study of Students's Thesis of Early Childhood Education Teacher Education Program
}

\author{
Peny Husna Handayani ${ }^{1 *}$, Anita Yus, Damaiwaty Ray $^{2}, \&$ Lala Jelita Ananda ${ }^{3}$ \\ $\{$ *peny_husna@unimed.ac.id\} \\ Faculty of Education, Universitas Negeri Medan, Medan, Indonesia ${ }^{1}$
}

\begin{abstract}
This study aims to map students' thesis on Early Childhood Education Teacher Education Program (PG PAUD) UNIMED FIP from 2011 to 2015. This type of research is quantitative research with a bibliomteric approach. The object of the research is in the form of a thesis for undergraduate students of teacher education programs for early childhood education (PG-PAUD). Data processing methods are carried out through stages (1) data collection, conducted by focusing on aspects of research topics, research subjects, types and methods of research, analysis techniques and references (2) data entry; (3) data analysis; (4) make tabulations according to observation requirements; and (5) descriptive interpretation. The results show that the topic of the most independent variables that appear most frequently in student theses over the past 5 years is the topic of play, which is as much as $32 \%$. The topic of the free variables used so far varies greatly. Cognitive abilities and interpersonal abilities become topics of dependent variables that often appear, but are still in a small category. The topic of the independent and dependent variables for PG-PAUD research is still much that needs to be studied and studied further. The type of research that dominates the PG-PAUD FIP UNIMED thesis during the last five years is Classroom Action Research (CAR) and experiments, each of which appears as much as $44.9 \%$. Other types of research have not been widely carried out. The research subjects used in PG-PAUD students' thesis almost all (80.8\%) are children aged 5-6 years (group B), while children aged 4-5 years (group A), PAUD teachers, parents who having early childhood and first grade elementary school students is only a small part of the subject of PG-PAUD thesis research.
\end{abstract}

Keywords: Bibliometrics, thesis, PG-PAUD, research topic, type of research, subject of research

\section{Introduction}

Education in college aims to prepare students to become members of the community who have academic and professional abilities. Every college has special provisions and requirements that must be taken for student graduation. One of these conditions is that students are required to write a final assignment.

The final assignment of students that must be written in taking the level of education is the thesis writing. Thesis is a kind of scientific essay that describes an important subject in a branch of science as a result of literature and / or field research conducted by a student based on academic assignments from his college [1]. The thesis is prepared based on a student's research and is intended as a final proof of the quality of his scientific thinking, his ability to integrate all the knowledge that has been learned during his study, especially to solve a 
problem scientifically or as an effort of every student at the end of his studies to make a real contribution to the progress of science cared for by his faculty[2].

Ideally the thesis must be able to answer the existing problems in accordance with the development of the field of science studies. The studies that have been carried out can become a foothold for the development of further research. The conditions in the Medan State University FIP especially the Early Childhood Education Teacher Education Program (PG PAUD), students are less aware of the direction of the research to be conducted. Most students only see the existing thesis examples without seeing the problems and conditions in the environment according to their scientific fields.

This is in accordance with Januarti's (2009) study that the constraints that are commonly faced by students in writing thesis are the constraints of determining the title or problem that exists. [2] also identified some of the problems of students in compiling a thesis, one of which is the title of the thesis, mostly not the result of identification of learning problems in school, but reading the thesis before.

The unclear mapping of the thesis written by PG PAUD students makes it difficult for future researchers to determine the research and planning that must be done. In addition, it can cause repetition of problems to be examined, so that the next impact is the results of student research written in the thesis does not indicate the existence of scientific progress in the field of teacher education for early childhood education.

Mapping of a good thesis should reflect the research activities that have been carried out, so that it can provide further research predictions. Therefore, it is very important to do a thesis bibliometric study of students of Early Childhood Education Teacher Education (PG PAUD) to map the extent of the problems, methods and subjects of research that have been conducted in order to build a research mapping of PG PAUD, FIP, Medan State University, so it is expected to reduce repetition the problems studied and can develop the field of PG-PAUD studies.

\section{Methodology}

his type of research is quantitative research with documentation survey method or known as bibliometrics. The research subjects were undergraduate thesis students of teacher education programs for early childhood education (PG-PAUD). Data collection methods are carried out by means of documentation through inspection and recording. The research procedure adapts [3] bibliometric study method, namely (1) data collection; (2) data entry; (3) data analysis; (4) make tabulations according to observation requirements; and (5) descriptive interpretation.

In this study the data was taken not from the entire population of the 2011-2015 PGPAUD student thesis, but only the PG-PAUD thesis was taken from 2011-2015. Thesis samples used in this study amounted to 78 theses of PG-PAUD students in the last five years.

The data in this study are information in the thesis covering research topics, research subjects, types and methods of research, and data analysis techniques. The data comes from the thesis of students of the Early Childhood Education Teacher Education program (PGPAUD). The data processing is carried out through stages: (1) data collection, conducted by focusing on aspects of research topics, research subjects, types and methods of research, and data analysis techniques; (2) data entry; (3) data analysis; (4) make tabulations according to observation requirements; and (5) descriptive interpretation. 


\section{Result and Discussion}

Based on the thesis data collection of PG PAUD FIP UNIMED students from 2011-2015 a sample of 78 theses was obtained. Table 1 shows the distribution of the topic of the independent variables that appeared in the PG PAUD FIP UNIMED thesis during the last five years (2011-2015).

Table 1. Topic of Independent Variables that Appear in Thesis PG PAUD FIM UNIMED 2011

\begin{tabular}{clccc}
\hline No & \multicolumn{1}{c}{ Independent Variables Topic } & Frekuency & $\mathbf{\%}$ & Categorization \\
\hline 1 & Play & 25 & $32 \%$ & Almost half \\
2 & Story Telling & 7 & $9 \%$ & In part \\
3 & Use of Media (Images, Cards, Audio & 6 & $7,7 \%$ & In part \\
& Visual, Manipulaif, story books) & & & \\
4 & Dancing, Music, Motion & 6 & $5,4 \%$ & In part \\
5 & Learning model & 6 & $5,4 \%$ & In part \\
6 & Drawing Activities & 3 & $3,8 \%$ & In part \\
7 & Role of Parents / Parenting & 3 & $3,8 \%$ & In part \\
8 & Demonstration Method & 3 & $3,8 \%$ & In part \\
9 & Conversation Method & 3 & $3,8 \%$ & In part \\
10 & Teacher Professional Allowance & 3 & $3,8 \%$ & In part \\
11 & Others (Motivation, Reward, Leadership & 12 & $15 \%$ & In part \\
& Style, Jarimatika Technique, & & & \\
& Experimental Method, Batik, etc.) & & & \\
\hline
\end{tabular}

Based on Table 1, it can be seen that the topic of play has become the most frequent topic in the thesis of the students of PG PAUD FIM UNIMED for the last five years (2011-2015), namely as much as $32 \%$ or almost half, followed by the topic of storytelling or storytelling reaching $9 \%$, usage media both image, card, audio visual media, manipulative media and story books as much as 7.7\%, dancing, music and motion as much as $5.4 \%$, learning models (contextual models, make a match, number head together) of $5.4 \%$. Another group on the topic of independent variables as much as $15 \%$ showed the There are no independent variable topics that dominate the thesis study of PG-PAUD students, although the topic of play appears as much as $32 \%$ or almost half, but it cannot be said to dominate because in categorization it is still less than half. The topic of the independent variables used in the thesis of PG-PAUD students varies. The creative world of PG-PAUD makes PG-PAUD variability of the topic of the independent variables used in the thesis study of PG PAUD UNIMED students during 2011-2015.

students kratif in determining the topic of independent variables in thesis research, as the final project of PG-PAUD students. This also shows that the topic of independent variables from existing PG-PAUD studies still needs to be studied and studied further.

Next the topic of the dependent variable that appears in the PG PAUD FIM UNIMED thesis for the last two three years (2011-2015) is shown in table 2.

Table 2. Topics of Dependent Variables that Appear in Thesis PG PAUD FIP UNIMED 2011-2015

\begin{tabular}{llccc}
\hline No & \multicolumn{1}{c}{ Dependent Variables Topic } & Frecuency & \% & Categorization \\
\hline 1 & Kemampuan Kognitif & 9 & $11,5 \%$ & In part \\
2 & Kemampuan Interpersonal & 9 & $11,5 \%$ & In part \\
3 & Kreativitas & 7 & $9 \%$ & In part \\
\hline
\end{tabular}




\begin{tabular}{llccc}
\hline No & Dependent Variables Topic & Frecuency & \% & Categorization \\
\hline 4 & Perilaku Sosial & 6 & $7,7 \%$ & In part \\
5 & Kecerdasan visual spasial & 6 & $7,7 \%$ & In part \\
6 & Motorik Kasar & 5 & $6,4 \%$ & In part \\
7 & Motorik Halus & 5 & $6,4 \%$ & In part \\
8 & Kemampuan bicara & 4 & $5 \%$ & In part \\
9 & Kecerdasan emosi & 3 & $3,8 \%$ & In part \\
10 & Pengenalaan lambang bilangan & 3 & $3,8 \%$ & In part \\
11 & Kinerja Guru & 3 & $3,8 \%$ & In part \\
12 & Kemampuan bahasa & 2 & $2,7 \%$ & In part \\
13 & Kosakata Anak & 2 & $2,7 \%$ & In part \\
14 & Kemampuan Membaca & 2 & $2,7 \%$ & In part \\
15 & Kecerdasan Kinestetik & 2 & $2,7 \%$ & In part \\
16 & Lain-lain (Moral Anak, & 10 & $12,8 \%$ & In part \\
& Kemampuan Menyimak, & & & \\
& Kemampuan menulis, motivasi & & & \\
& guru, motivasi anak, kemapuan & & & \\
& pemecahan masalah matematika, & & & \\
& penyelenggaraan PAUD, kemapuan & & & \\
& sains, kemampuan musikal, & & & \\
berhitung) & & & \\
\hline
\end{tabular}

Based on Table 2, it can be seen that the topic of cognitive abilities and interpersonal abilities is the topic of bound variables that most often appears in the thesis of PG PAUD FIP UNIMED students for the last five years (2011-2015), which is as much as $11.5 \%$, followed by the topic of creativity reaching $9 \%$, social behavior and spatial visual intelligence appear as much as $7.7 \%$, gross motor and fine motoric become the topic of dependent variables that appear as much as $6.4 \%$, speech ability appears as much as $5 \%$, emotional intelligence and number recognition appear as much as $3.8 \%$, language skills, children's vocabulary, reading ability and kinesthetic intelligence of munucl were $2.7 \%$. The other groups on the topic of bound variables as much as $12.8 \%$ show the variability of the topic of the dependent variable used in the thesis study of the PG PAUD UNIMED students during 2011-2015. Table 2 above shows the variable bound variable is more varied than the topic of the independent variables that appear in the thesis of PG PAUD 2011-2015 students.

As with the topic of independent variables, none of the topics of the dependent variable dominated the thesis study of PG-PAUD students. All the topics of the dependent variable that appear are in a minority categorization, meaning that the topics of the dependent variable that appear in the PG-PAUD thesis in the last five years can still and need to be studied and studied further. The world of PG-PAUD that is full of creativity makes the topic of the dependent variable appear to be varied.

The distribution of research methods used in the PG PAUD FIP UNIMED thesis during the last five years (2011-2015) is shown in table 3 .

Table 3. Types of Research in the Thesis of PG-PAUD Students in 2011-2015

\begin{tabular}{clccc}
\hline No & Types of Research & Frekuency & \% & Categorization \\
\hline 1 & Classroom action research & 35 & $44,9 \%$ & Almost half \\
2 & Experiment & 35 & $44,9 \%$ & Almost half \\
3 & Comparative & 4 & $5,1 \%$ & In part \\
\hline
\end{tabular}




\begin{tabular}{clccc}
\hline No & Types of Research & Frekuency & \% & Categorization \\
\hline 4 & Corelation & 3 & $3,8 \%$ & In part \\
5 & Descriptive & 2 & $2,6 \%$ & In part \\
\hline
\end{tabular}

Based on table 3 it can be seen that the type of research that is often used by students in the work of the UNIMED FIP PG PAUD thesis over the last five years (2011-2015) is PTK and experiments, which is as much as $44.9 \%$ or almost half of the existing research. Other types of research such as comparative, correlation, and descriptive have not been done much. This is important information that needs to be followed up, for example by motivating students to conduct descriptive, choreal, or comparative research. [4] states that educational research in accordance with its characteristics can take the form of descriptive, analytical, explorative, experimental, case studies, historical, and comparative studies.

The research subjects used in the PG PAUD FIP UNIMED thesis during the last five years (2011-2015) are shown in table 4.

Table 4. Research Subjects in Student Thesis in 2011-2015

\begin{tabular}{clccc}
\hline No & \multicolumn{1}{c}{ Research Subjects } & Frekuency & $\mathbf{\%}$ & Categorization \\
\hline 1 & Children aged 5-6 years (Group B) & 63 & $80,8 \%$ & Almost all \\
2 & Children aged 4-5 years (Group A) & 9 & $11,5 \%$ & In part \\
3 & Teacher of Early Childhood & 4 & $5,1 \%$ & In part \\
4 & Parents Who Have Early Childhood & 1 & $1,2 \%$ & In part \\
5 & Grade 1 elementary school students & 1 & $1,2 \%$ & In part \\
\hline
\end{tabular}

Based on Table 4 it can be seen that almost all of the research subjects were used by students in the work of the UNIMED FIP PG PAUD thesis for the last five years (2011-2015) were children aged 5-6 years (group B), as many as $80.8 \%$, while children aged 4-5 years (group A), PAUD teachers, parents who have early childhood and first grade elementary school students are only a small part of the subject of PG-PAUD thesis research. This is an important information that needs to be followed up, namely by motivating students to conduct research with the subjects of the study are children aged 4-5 years (Group A), PAUD teachers, parents who have early childhood, and first-class students SD, all of which are still related to the scope of PG-PAUD.

\section{Conclusion}

The results show that the topic of the most independent variables that appear most frequently in student theses over the past 5 years is the topic of play, which is as much as $32 \%$. The topic of the free variables used so far varies greatly. Cognitive abilities and interpersonal abilities become topics of dependent variables that often appear, but are still in a small category. The topic of independent and dependent variables for PG-PAUD research is still much that needs to be studied and studied further. The type of research that dominates the PGPAUD FIP UNIMED thesis during the last five years is Classroom Action Research (CAR) and experiments, each of which appears as much as $44.9 \%$. Other types of research have not been widely carried out. The research subjects used in PG-PAUD students' thesis almost all $(80.8 \%)$ are children aged 5-6 years (group B), while children aged 4-5 years (group A), 
PAUD teachers, parents who having early childhood and first grade elementary school students is only a small part of the subject of PG-PAUD thesis research.

This mapping can be used as a guideline for the management of the thesis in the PGPAUD study program in order to be able to direct student thesis research so as to produce thesis research that can provide a large contribution to the progress of science in the field of PG-PAUD.

Academic supervisors and thesis advisers should know the mapping of thesis research and direct students to realize the proportionalisation of student thesis research, to avoid repeated research without creativity.This mapping, allows for further research in more detail and depth, according to a certain period of time.

\section{References}

[1] R. Januarti, "Hubungan antara persepsi terhadap dosen pembimbing dengan tingkat stress dalam menulis skripsi." Univerversitas Muhammadiyah Surakarta, 2009.

[2] Parmin, "Peningkatan Kemampuan Mahasiswa dalam Menyusun Proposal Skripsi," . J. Pendidik. IPA Indones. Vol 1(2) 183-191., 2012.

[3] H. Himawanto, "Kajian Bibliometrik Riset Minyak dan Gas Bumi Nasional 1990-2014," Khizanah al-Hikmah J. Ilmu Perpustakaan, Informasi, dan Kearsipan, vol. 3, no. 1, pp. 49-63, 2015.

[4] S. Danim, "Metode Penelitian untuk Ilmu-ilmu Perilaku. Acuan Dasar Bagi Mahasiswa Program Sarjana dan Peneliti Pemula," FirstPrinting. Jakarta Bumi Aksara, 1997. 